\title{
Organic matter characterization in the sea surface microlayers in the subarctic Norwegian fjords region
}

\author{
Blaženka Gašparovića*, Marta Plavšića ${ }^{a}$, Božena Ćosovića ${ }^{a}$, Alain Saliot ${ }^{\mathrm{b}}$ \\ ${ }^{a}$ Center for Marine and Environmental Research, Ruđer Bošković Institute, POB 180, HR-10002 \\ Zagreb, Croatia, ${ }^{b}$ LOCEAN, Laboratoire d'Océanographie et du Climat, Expérimentations et \\ Approches Numériques, Université Pierre et Marie Curie, IPSL/UPMC/IRD/MNHN, UMR CNRS \\ 7159, Case courrier 100, 4 place Jussieu, F-75252 Paris Cedex 05, France
}

\begin{abstract}
*Corresponding author. Tel.: +385 14561 148; fax: +385 14680242.
E-mail address: gaspar@irb.hr (B. Gašparović)
\end{abstract}

\begin{abstract}
The uppermost layer of the ocean, the sea surface microlayer (ML), covers more than 70 $\%$ of the world's surface. It is a sink for natural and anthropogenic material that determines its chemical composition. This article is aimed at providing novel data on the characterization of organic matter in ML and underlying waters (ULW) in the rarely investigated subarctic, north Norwegian fjords region, in July 2001, August 2002 and June 2003. A multiparameter approach was used, including DOC measurements, characterization of surface-active organic substances (SAS), determination of $\mathrm{Cu}$ complexing capacity $\left(L_{T}\right)$ and specific analysis of fatty acids (FA). The characteristics of organic matter in the fjords' sea surface microlayers showed that organic substances in the films were mainly produced in the subsurface water. There was negligible fractionation of hydrophobic substances to the microlayer and even depletion of fatty acids was found in some ML samples. Fjords' surface waters were found to be very rich in fatty acids in July, up to $188 \mu \mathrm{g} / \mathrm{l}$, with high contributions of polyunsaturated compounds. The enrichment of DOC and SAS concentrations in the ML as compared to the ULW was in the range of $1.2-2.8$, while higher enrichment factors $(1.3-5.1)$ were determined for copper complexing ligands, indicating increased contribution of hydrophilic, lower molecular weight molecules. The detected characteristics and concentrations of organic substances in the surface microlayer and adjacent subsurface water differ for each month of sampling.
\end{abstract}


Keywords: sea surface microlayer, organic matter; fatty acids; $\mathrm{Cu}$ complexing capacity; surfactant activity; subarctic fjords; Norway

\section{Introduction}

Most biogeochemical processes in natural waters take place at different phase boundariess, among which the largest one is the atmosphere-ocean boundary. The sea surface microlayer is a unique environment. Due to the enrichment of chemicals and biota within the sea surface microlayer, there is the widely held presumption that the surface microlayer could act as a highly efficient and selective microreactor, effectively concentrating and transforming materials brought to the interface from the atmosphere and oceans by physical processes.

The chemical composition and physicochemical properties of organic matter in natural sea surface films reveal the presence of a complex mixture of molecules covering a wide range of solubility, surface activity and molecular masses with an apparent structural organization exhibiting a spatial and temporal variability (Pogorzelski and Kogut, 2003; Kozarac et al., 2005; Ćosović, 2005). The organic matter in sea surface microlayers is composed of proteins, polysaccharides, humic-type material and waxes, and strongly surface active lipids. Lipids play a key role in the establishment of surface films (Garrett, 1967; Brinis et al., 2004). In addition, fatty acids, as a main component of lipids, are key tracers for studying chemical and physical processes (photooxidation, evaporation into the atmosphere, polymerization, and flocculation) complementary to biological activities (Saliot, 1994). The chemical composition of the ML is dependent on the chemical fractionation of organic matter at the air/sea boundary. Organic matter may originate from in situ production, from the underlying water and from atmospheric deposition. Phytoplankton exudates and their degradation products are the major sources of marine surfactants (Žutić et al., 1981). Production of this material appears to be seasonal and has been linked to biological productivity cycles (Ćosović et al. 1985; Gašparović and Ćosović 2001, 2003). A mean molecular mass of surfactants, $M_{w}$, of 0.65 to $9.7 \mathrm{kDA}$ has been reported for samples from the Baltic Sea and the Mediterranean (Pogorzelski and Kogut, 2003). Higher $M_{w}$ values were 
found in subsurface water samples as compared to microlayer samples collected under calm sea conditions (Pogorzelski and Kogut, 2003).

Valuable information concerning the nature and properties of organic substances in natural waters can be obtained by studying the interaction of metal ions with organic matter (Buffle, 1988; Paulson et al., 1994; Plavšić et al., 2006), which could influence their availability to aquatic organisms and their association with particles and sediments in the system. The amount of complexing ligands can be determined by the titration of the sample with a standard copper solution and following the progress of the titration with anodic stripping voltammetry (DPASV) (Plavšić et al., 1982).

The objective of the present study was to investigate and characterize organic matter in the sea-surface microlayers in the Norwegian subarctic fjords, a region that has been poorly investigated for organic matter up to now. The characteristics of the investigated microlayers were compared to the underlying water for the estimation of enrichment of organic substances between bulk water and the top layer of the seawater. There are only a few measurements from the surface microlayers in high latitude areas anywhere (Knulst et al., 2003; Calace et al., 2004; Bigg et al., 2004; Leck and Bigg, 2004). The investigated North Norwegian fjords are characterized by relatively high temperature for high-latitude fjords and negligible influence by glaciers. The amount of solar irradiation and day length periodicity create particular conditions for the seasonal progression of biological processes in the fjords. Ambient solar radiation in this region in the spring-summer period has marked inhibitory effects on phytoplankton photosynthetic rates (Helbling et al., 1996). Here, in studying sea surface microlayers, major attention was given to surface active properties of organic substances owing to their expected dominant role in processes at the air/sea phase boundary.

\section{Experimental}

Nine pairs of sea surface microlayer and the underlying seawater samples were collected in subarctic Norwegian fjords, in late spring and summer in 2001, 2002 and 2003. 


\subsection{Study area}

The samples were collected in July 2001 (samples 1 and 2), August 2002 (samples 3 and 4) and June 2003 (sample 5) in the Tromsø region of North Norwegian fjords (Figure 1). The city of Tromsø has more than 60000 inhabitants. The sampling sites 1, 3 and 4 are located in populated areas, site 5 in a less populated area and site 2 in an unpopulated region. In the vicinity of Station 1, in Blamannsvik fjord, there is a factory for processing prawns as well as a fish farm. Also, there is a small river entering the small fjord. Station 2, in Ullsfjord, is not influenced by industry or any significant anthropogenic input. Ullsfjord is wide and open; it is exposed and separated from the shelf by a sill of $170 \mathrm{~m}$ depth. Ullsfjord is characterized by higher temperature and salinity compared to Balsfjord (Station 5), due to the stronger influence of shelf waters. Station 3 is situated in the vicinity of the city of Tromsø and could be influenced by the discharge of treated sewage from the city. Station 4 represents semienclosed water. It could be influenced by the ship yard in Eidkjosen. Station 5 is located at the entrance of Balsfjord. Its waters are well mixed with water from Malangen fjord and the outer coast. Station 5 could be influenced by the river runoff from Malangen fjord. The freshwater discharge to North Norwegian fjords is highly seasonal; however it is not prominent until the main snow melting takes place in late May and June.

General environmental conditions are presented in Table 1. Air temperatures were between 10 and $20{ }^{\circ} \mathrm{C}$, seawater temperatures were between 11 and $14{ }^{\circ} \mathrm{C}$, and sea surface microlayer temperatures were higher than in the underlying water by 1 to $2.5^{\circ} \mathrm{C}$ and were even higher by $6{ }^{\circ} \mathrm{C}$ for the sample taken at early June, 2003. Data on solar irradiation and wind speed are presented in Table 1 as well.

\subsection{Sample collection and preparation}

Sea surface microlayer samples were collected mostly under calm conditions, from a rowed rubber boat. Sampling was performed with a Garrett-type screen made of stainless steel, with $1.06 \mathrm{~mm}^{2}$ mesh size and $0.24 \mathrm{~mm}$ wire diameter. The sampling was performed by dipping the screen through the sea surface. It was then withdrawn horizontally through the sea surface and drained immediately into a sample bottle (Garrett, 1965). The thickness of the 
sampled microlayer was approximately $100-150 \mu \mathrm{m}$. The screen method is found to be the most useful technique because of its relatively short sampling time and large sample volume (Falkowska, 1999; Momzikoff et al., 2004). Underlying water was collected by immersing a 1 1 glass bottle at a depth of $\sim 10 \mathrm{~cm}$.

To separate particulate and dissolved organic material, seawater samples were manually filtered $(-50 \mathrm{kPa})$ immediately after the sampling, using precombusted $\left(450{ }^{\circ} \mathrm{C} / 5 \mathrm{~h}\right)$ Whatman $\mathrm{GF} / \mathrm{F}$ glass fibre filters $(0.7 \mu \mathrm{m}$ pore size $)$ on a Millipore all-glass filter holder.

The unfiltered samples for complexing capacity measurements were frozen $\left(-20{ }^{\circ} \mathrm{C}\right)$ immediately after sampling and were kept so, for one month (ISO 5667-3:1994), until analysis were performed. Prior to analysis, the samples were maintained at room temperature overnight $\left(18-20{ }^{0} \mathrm{C}\right)$ for complete thawing.

Sample bottles were cleaned first with chromic-sulphuric acid, and subsequently with 10 $\%$ nitric acid and properly rinsed with Milli-Q water. A screen for microlayer sampling was washed-out with ethanol, Milli-Q water, $10 \%$ nitric acid, Milli-Q water and properly rinsed again in the seawater for prolonged time before sampling.

Seawater temperature was measured on board immediately after the sampling with a mercury-in-glass hand thermometer that has the scale graduated by one degree. Hence, the overall accuracy would be $\pm 0.5^{\circ} \mathrm{C}$. The salinity was measured with an Atago S-10 (Japan) hand refractometer with an accuracy of 1 salinity unit.

\subsection{DOC analysis}

The DOC concentrations were determined by using a sensitive high temperature catalytic oxidation (HTCO) technique. A Model TOC-500 System (Shimadzu) with highly sensitive Pt catalyst and a non-dispersive infrared (NDIR) detector for $\mathrm{CO}_{2}$ measurements was used. The blanks for DOC were less than $3 \%$, respectively, of the lowest detected concentration. The overall average standard deviation was $0.04 \mathrm{mg}^{-1}(\mathrm{n}=30)$. Some cuvettes were broken during transport so some data are missing.

\subsection{Fatty acid analyses}


Total lipids were extracted by dichloromethane for fatty acid analysis. Briefly, after conversion into methyl esters the fatty acids were analysed by capillary gas chromatography and structures confirmed by mass spectrometry; details are given elsewhere (Derieux et al., 1998; Brinis et al., 2004). Fatty acid (FA) analysis allows a distinction to be made between autochthonous and allochthonous sources of organic matter (Saliot et al., 2002). The different FA groups are characteristic for different origins: polyunsaturated fatty acids (PUFA) and monounsaturated fatty acids (MUFA) are important in phytoplankton and zooplankton and represent fresh material; branched fatty acids (BrFA) in the carbon number range 15-19, mainly iso and anteiso compounds, are commonly used as bacterial markers together with saturated FA with 15 and 17 carbon atoms. Material of terrestrial origin is characterized by the presence of saturated fatty acids with more than 22 carbon atoms.

The detection limit was $6 \mathrm{ng} / \mathrm{l}$ and the precision was about $3-10 \%$ in absolute weight. Fatty acids are designated for example as $18: 1 \omega 7$, where 18 is the total number of carbon atoms, 1 is the number of double bonds and 7 is the position of the double bond in the carbon chain from the terminal methyl group as indicated by the Greek letter omega.

\subsection{Characterization of SAS}

Surface active substances (SAS) were analyzed by nondestructive electrochemical methods. Using o-nitrophenol as an electrochemical probe, as described in previous papers (Gašparović and Ćosović, 1994; 1995; 2001), concentration of SAS (surfactant activity-SA) of the complex mixture of organic substances in natural seawater samples is determined as the equivalent concentration of the nonionic surfactant Triton-X-100 (T-X-100). The relative acidity of organic substances in the seawater sample is determined from the increase of the onitrophenol prepeak height and comparison with the effects of the selected model substances (Gašparović et al., 1998a; Gašparović and Ćosović, 2003). Total SAS (SAS $\mathrm{T}$ ) were determined from the unfiltered sample, while dissolved SAS ( $\left.\mathrm{SAS}_{\mathrm{diss}}\right)$ were determined from the filtered sample, and the difference between concentration of total SAS and dissolved SAS is arbitrarily called "particulate SAS" (SAS"p").

Adsorption effects of SAS at the mercury electrode were measured by phase sensitive alternating current voltammetry (out-of-phase measurements) (Ćosović and Vojvodić, 1982). The method is based on the principle that adsorption of SAS causes a decrease of the double 
layer capacitance which depends on the quantity and the hydrophobic properties of SAS. A second property that is followed is the appearance of desorption peaks whose desorption potentials as well as shapes are substance-related (Vojvodić et al., 1994).

Adsorption properties were investigated in the original natural samples and in the ex-situ reconstructed films (Gašparović et al., 1998b). Ex-situ reconstructed films were made by spreading extracted lipids at room temperature on aqueous $0.55 \mathrm{~mol} / 1 \mathrm{NaCl}$ solution as the subphase and then transferring them to the mercury electrode by vertically dipping the electrode through the film (Nelson and Benton, 1986; Kozarac et al., 1991).

\subsection{Cu complexing capacity determination}

The complexing capacity was determined in nonfiltered (untreated) samples comprising both particulate and dissolved ligands. Determination was performed by the direct titration method of the sample with increasing amounts of copper ions and their electrochemical determination by the method of DPASV. The peak currents, resulting from the oxidation of voltammetric-labile copper, are plotted against the added copper concentration yielding a titration graph. The labile copper fraction detected by this technique is hydrated $\mathrm{Cu}^{2+}$ or $\mathrm{Cu}$ ions bound to inorganic or organic complexes whose dissociation kinetics are so rapid for the applied method (depending on the electrode diffusion layer thickness) that they are detected as electroactive. Strong metal-ligand complexes do not dissociate and are not reduced at the chosen fixed potential. This provides for labile/inert discrimination data. To obtain complexing capacity values and conditional stability constant, titration data are linearly transformed assuming a 1:1 metal to ligand complexes (Ružić, 1982). Equation used for calculation is: $[\mathrm{Cu}] /[\mathrm{CuL}]=[\mathrm{Cu}] / \mathrm{L}_{\mathrm{T}}+1 / \mathrm{KL}_{\mathrm{T}}$, where $\mathrm{Cu}$ is the copper ion detected by anodic stripping voltammetry, $\mathrm{CuL}$ is the copper ion bound in a complex, $\mathrm{L}_{\mathrm{T}}$ is the concentration of binding ligands (i.e. complexing capacity) and $\mathrm{K}$ is the conditional stability constant. $[\mathrm{Cu}]$ and $[\mathrm{CuL}]$ are calculated from the titration data, where: $[\mathrm{Cu}]=I_{p} / \mathrm{S}$ and $[\mathrm{CuL}]=\left[\mathrm{Cu}_{\mathrm{T}}\right]-[\mathrm{Cu}]$. In that equations: $I_{p}$ is the height of DPASV detected copper peak, $\mathrm{S}$ is the sensitivity of the DPASV method to labile copper which corresponds to the slope of the linear portion of the titration graph after all complexing sites are saturated with copper ions, $\left[\mathrm{Cu}_{T}\right]$ is the concentration of copper ion added + copper ion originally present in the sample. The plot of: $[\mathrm{Cu}] /[\mathrm{CuL}]$ versus $[\mathrm{Cu}]$ yields a straight line with a slope of $1 / \mathrm{L}_{\mathrm{T}}$ and intercept $1 / \mathrm{KL}_{\mathrm{T}}$. The 
detailed procedure (Plavšić, 2003; Scoullos et al., 2004) and calculations have been described elsewhere (Ružić, 1982; Van den Berg, 1982). The same method of calculation is applied in other papers, e.g. Bazzi et al., 2002 and Andrade et al., 2006.

\section{Results}

The characteristics of the investigated sea surface microlayers and underlying waters are presented in Tables 2, 3, 4 and 5. Enrichment factors (EF) were calculated as the ratio of the concentration of a certain parameter in the given sea surface microlayer (ML) sample to that in the corresponding underlying water (ULW).

\subsection{Organic matter distribution in the sea surface microlayer and the underlying water}

DOC values (Table 2) varied in a range between 1.67 and $2.83 \mathrm{mg} \mathrm{C/1} \mathrm{for} \mathrm{all} \mathrm{ML}$ samples, while for the ULW samples DOC values were in the range between 1.21 and 1.85 $\mathrm{mg} \mathrm{C} / 1$. DOC enrichment factors were in the range between 1.19 and 1.87 , with an average of 1.55. The lowest DOC values were found in June, the highest in July. Vertical distributions of organic matter (DOC, POC, PON) and chlorophyll $a$ values, starting from the surface microlayer and underlying water down to the $60 \mathrm{~m}$ depth at station 5 in June 2003, are presented in Table 3. The characteristic molar POC/PON ratio of the samples was around 10 for the surface water and in the deeper layer below $50 \mathrm{~m}$ depth. Lower POC/PON values were determined at the middle depths, which correlates with increased values of the chlorophyll $a$ in the same samples.

\subsection{Fatty acids}

Fatty acid distribution can be used to distinguish between various sources. The abundance of MUFA and PUFA versus saturated fatty acids (SAFA) provides information on the state of degradation of organic matter, as the degree of instability of FA is directly dependent on the 
number of double bonds (Goutx and Saliot, 1980). The results of fatty acid analyses are presented in Table 4. Total FA concentrations vary from 2.1 to $188.3 \mu \mathrm{g} / \mathrm{l}$. In the majority of the investigated samples saturated fatty acids (SAFA) were dominant in the fatty acid fraction (30 to $86 \%$ ). Exceptions were ML and ULW of sample 1a where major contributors to the fatty acid pool were unsaturated fatty acids.

PUFA represent fresh material, as they are very labile compounds. PUFA contributions to the total FA were between 0.4 and $43.1 \%$. Higher concentrations were found in July 2001 . Total polyunsaturated FA $\mathrm{C}_{20: 5}$ and $\mathrm{C}_{22: 6}$ were enriched in the ML. $\mathrm{C}_{20: 5}$ and $\mathrm{C}_{22: 6}$ are often the major FA in phyto- and zooplankton (Sargent et al., 1976). Exceptionally high $\mathrm{C}_{20: 5}$ and $\mathrm{C}_{22: 6}$ concentrations were found in ML 1a and ULW 1a; 19.9 and $11.9 \mu \mathrm{g} / 1$, respectively.

Branched FA (BrFA) including also saturated FA $\mathrm{C}_{15: 0}$ and $\mathrm{C}_{17: 0}$ (Goosens et al., 1986; Saliot et al., 1988) are markers for bacterial biomass and activity. BrFA contributions to the total FA were between 3.4 and $12.1 \%$. Higher concentrations were found in July 2001. BrFA were depleted in the ML compared to the ULW in $2001(\mathrm{EF}<1)$ and were enriched in 2002 and $2003(\mathrm{EF}>1)$.

High molecular weight $\mathrm{FA}, \mathrm{C}_{22: 0}, \mathrm{C}_{24: 0}$ and $\mathrm{C}_{26: 0}$, are indicators of terrigenous material (Caldicott and Eglinton, 1973). They were found in detectable concentrations only at station 5 in 2003: $0.34,0.39$ and $0.22 \mu \mathrm{g} / 1$, respectively. The enrichment factors in ML 5 were 8.1, 5.9 and 5.3, respectively.

\subsection{Surface-active substances}

Total concentrations of SAS $\left(\mathrm{SAS}_{\mathrm{T}}\right)$ (Table 2), obtained from the nonfiltered samples, in the MLs were in the range of 0.121 to $>0.21 \mathrm{mg} / 1$ in equiv. of T-X-100 (Gašparović and Ćosović, 2001), and averaged $\sim 0.16 \mathrm{mg} / 1$. The $\mathrm{SAS}_{\mathrm{T}}$ in the ULWs were in the range of 0.075 $-0.138 \mathrm{mg} / \mathrm{l}$, and average $0.11 \mathrm{mg} / 1$ in equiv. of T-X-100. Enrichments of total SAS in the ML samples, as indicated by enrichment factors, were in the range of 1.21 to $>2.8$, with average of approx. 1.5. The contribution of the SAS obtained as the difference between $\mathrm{SAS}_{\mathrm{T}}$ and SAS $_{\text {diss }}($ SAS"p") in the ML was quite variable, from 4 to $25 \%$, while in the ULWs it was in the range of 5 to $18 \%$. 
Valuable information on the organic matter characteristics may be also gained by examining surfactant activity (concentration of SAS) values normalized to DOC concentration (SA/DOC) measured in the same seawater samples. A higher SA/DOC ratio indicates a higher contribution of hydrophobic substances to the bulk organic matter. As determined from the behavior of model substances, the highest contribution to surfactant activity can be ascribed to highly hydrophobic substances such as fatty acids (SA/DOC is 2.39 for linoleic acid), for humic acids and proteins values are $0.19-0.34$, while some polysaccharides like xanthan have a low surfactant activity contribution to DOC (0.04).

As presented in Table 3 for the microlayer and bulk water samples at the station 5 in 2003, total surfactant activity values were normalized to the total organic carbon content $(\mathrm{DOC}+\mathrm{POC})$, while the data for $\mathrm{SAS}_{\text {diss }}$ were normalized to the DOC content. All normalized surfactant activity values fall in the range from 0.047 to 0.087 except one which is $>0.10$ for the nonfiltered microlayer sample. Higher values belong to the organic matter in the more productive upper water layer. We have not observed, in general, higher SA/DOC ratios for microlayer samples compared to the underlying seawater.

From the relative acidity values (Table 2) we attempted to estimate which type of organic material contributed to the surfactant activity, more acidic humic and fulvic surface-active organic matter (relative acidity 20-25 1/mg), or biogenic organic matter such as proteins, polysaccharides and lipids, having lower relative acidity $(2.5-15 \mathrm{l} / \mathrm{mg})$. The relative acidity values of organic matter in MLs were low, between 3 and $7.41 / \mathrm{mg}$. In the ULW samples relative acidities were in the range of $3.2-15.91 / \mathrm{mg}$. Some relative acidity values could not be estimated due to the limitation of the method that is usable for SA values lower than approx. $0.16 \mathrm{mg} / 1 \mathrm{~T}-\mathrm{X}-100$ (Gašparović and Ćosović, 2003).

The adsorption characteristics of naturally present organic substances in ML 3c and ULW 3c samples are compared with those of extracted lipids from ML 3c. In Fig. 2 the capacity current-potential curves are presented for ML and ULW samples from site $3 \mathrm{c}$, as well as for the dichloromethane extract of ex-situ reconstructed lipid film of the ML 3c. The decrease of the capacity currents recorded for ULW and ML 3c (curves 2 and 3, respectively) in respect to that of seawater without SAS adsorption (curve 1) can be clearly observed. This decrease is result of adsorption of SAS. Also, due to a higher concentration of SAS in the microlayer than in the underlying water the capacity current of ML detected at the starting potential (- 
$0.35 \mathrm{~V}$ ) is significantly lower than that corresponding to the ULW for the same adsorption time. The similar shape of the curves corresponding to ML and ULW samples indicates the presence of same types of organic substances, as well as a prevailing dominance of macromolecular organic substances (Vojvodić et al., 1994). The current-potential curve corresponding to ex-situ reconstructed film (curve 4 in Fig. 2) shows a shape typical for natural lipids, exhibiting a characteristic lipid desorption peak at a potential near $-1.2 \mathrm{~V}$ and differs significantly from that of original ML sample (curve 3).

\subsection{Cu complexing capacity}

In Table 5, total copper complexing capacity $\left(L_{T}\right)$ of the surface microlayer and underlying water samples are presented. They vary between 0.23 and $1.79 \mu \mathrm{M} \mathrm{Cu}{ }^{2+}$ for microlayer samples and 0.09 and $0.37 \mu \mathrm{M} \mathrm{Cu}^{2+}$ for underlying water samples. The highest complexing capacity value was obtained for the microlayer sample ML 1b from July 2001 amounting to $1.79 \mu \mathrm{M} \mathrm{Cu}^{2+}$. ML samples taken in August 2002 are characterized by the lowest $L_{T}$ values detected as well as by a small difference of $L_{T}$ values between MLs and ULWs. The highest EFs of complexing ligands are observed for samples from July 2001, 5.11 and 4.73. In August 2002 these values were considerably lower $(1.28-2.07)$.

The relative stability of the formed $\mathrm{Cu}$ complexes could be compared through the apparent stability constant $(\log K)$ values. Determined $\log K$ values for all samples are in the range of $6.8-7.8$. There is no significant difference in $\log K$ values calculated for microlayer samples and underlying seawater samples from the area.

Total copper concentrations (dissolved + particulate) were determined at $\mathrm{pH}=2.0$. In Fig. $3 \mathrm{~A}$ the copper ion concentrations $v s . \mathrm{CCu}$ values are presented for all the samples (sample $1 \mathrm{~b}$ is excluded as it showed exceptionally high $\mathrm{CCu}$ ). Copper ions concentrations were quite high $(0.3-100 \mathrm{nM})$, but these were coastal waters and total concentrations include dissolved and particulate $\mathrm{Cu}$, as the samples were not filtered. As can be seen $\mathrm{CCu}$ values are more or less constant for all copper ion concentrations determined, meaning that $\mathrm{CCu}$ are not influenced by the copper ion concentrations originally present in the samples. In the Fig. 3B two representative titration curves for samples ML 1a and ML 2 are presented, showing oxidation current as a function of added copper ion. Samples show no voltammetric-labile $\mathrm{Cu}$ at lower 
concentrations of added copper and curvature with increasing $\mathrm{Cu}$ additions, reflecting significant concentrations of excess ligands present in these samples.

The complexing capacity data normalized in terms of the DOC concentrations $\left(\mathrm{L}_{\mathrm{T}} / \mathrm{DOC}\right)$ measured in the same seawater samples (Mantoura, 1981; Scoullos et al., 2004) are given in Table 5. Higher values were in general calculated for microlayer samples, the highest 0.646 for ML 1b, July 2001. The normalized values for ULW were between $0.072-0.244$. Samples from August 2002, exhibit a similar amount of available complexing sites in microlayer and underlying samples. It follows that the dissolved organic ligands were more abundant in the organic matter pool in the microlayer samples compared to the bulk of dissolved organic carbon in the underlying water. Photochemical reactions in the ML would presumably destroy some of the $\mathrm{Cu}$-binding ligands, but also some additional $\mathrm{Cu}$ binding could be expected due to the sensitive photochemical processes and cycling of $\mathrm{Cu}$ between $\mathrm{Cu}^{2+}$ and $\mathrm{Cu}^{+}$in this layer (Voelker et al., 2000). Exposure to sunlight of marine surface microlayer samples (coastal and oceanic ones) resulted in the higher yields of low molecular weight carbonyl compounds in the surface microlayer than in the bulk seawater by a factor of $1.1-25$ suggesting the higher photoproduction rate of these compounds in the surface microlayer (Zhou and Mopper, 1997).

The value $\mathrm{L}_{\mathrm{T}} / \mathrm{SA}$, the complexing capacity data normalized to surfactant activity of the same seawater sample, gives information on complexing capacity of the part of the organic matter exhibiting at the same time surface active properties (Table 5). As can be seen the highest amount of this type of ligands has been present in the ML and ULW samples 1, taken in July, 2001, 8.3 and 2.7, respectively.

\section{Discussion}

The DOC values in the sea surface microlayers detected for the region of Norwegian subarctic fjords (Table 2) are comparable to other coastal, unpolluted seas. Taking into account that different authors use different methods of sampling sea surface film, i.e. collect films of different thickness (Zuev et al., 2001; Momzikoff et al., 2004), comparison is made only for the films sampled by the screen sampler. The reported DOC values for sea-surface films of the California coastal region were in range of $0.86-1.66 \mathrm{mg} / 1$, with a mean EF of 1.4 (Williams et al., 1986). For the North Adriatic Sea DOC values were 1.35, 1.39 and $3.24 \mathrm{mg}$ 
C/1 (Gašparović et al., 1998b). Significantly higher DOC values, from 4.2 to $20.4 \mathrm{mg} / 1$ were reported for the Chesapeake Bay region, which is a closed marine system highly influenced by urban and agricultural activities (Liu and Dickhut, 1998). According to Carlson (1993) the average microlayer DOC excess (ML concentration minus bulk water concentration) in data compiled from coastal and oceanic waters is around $1 \mathrm{mg} / 1$ with the result that most ML enrichment factors are small $(<2)$.

Total fatty acid concentrations in the surface waters of the north Norwegian fjords, up to $188 \mu \mathrm{g} / \mathrm{l}$, as determined in July 2001, are much higher than those reported for the Mediterranean Sea, 1 - 50 g/1 (Marty et al., 1988; Derieux et al., 1998; Gašparović et al., 1998b). This is in accordance with the observation that phytoplankton from colder waters are generally richer in lipid material (Sargent et al., 1977; Falk-Petersen et al., 1990). Higher contributions of PUFA and BrFA, which indicate higher plankton and bacterial abundances, were found in July. High levels of PUFA in plankton are due to the physiological importance of PUFA at low temperatures (Copeman and Parish, 2003). The contribution of the unsaturated FA to the total FA indicates that organic matter was really "fresh" as unsaturated acids are labile compounds, especially PUFA that are susceptible to UV and microbial degradation.

The observed surfactant activities as well as enrichment factors of SAS in the ML of north Norwegian fjords are comparable to those reported for MLs from early spring in the North Adriatic (Marty et al., 1988; Gašparović et al., 1998b). The enrichment factors of SAS in the Adriatic Sea that were published earlier are mainly more than 2, and are much higher in comparison to the enrichment of DOC (Ćosović et al., 1985). The surfactant enrichment in the ML of the north Norwegian fjords is on average similar to the DOC enrichment suggesting that more hydrophilic substances, that exhibit lower surfactant activities, are dominant in this natural boundary layer in the subarctic region at investigated season. In spite of the fact that fatty acids as the component of the lipid material were detected in considerable amounts in the north Norwegian surface seawater samples, they represent less than 10 percent of the organic matter content. The contribution of the lipid material to the total surfactant activity is not a dominant one. Indeed this is confirmed by the investigation of the adsorption characteristics of SAS in the original and ex-situ reconstructed films, as presented in Fig. 2. 
Very similar values of SA/DOC ratio were obtained for MLs and corresponding ULWs which imply that similar types of SAS contribute to the surfactant activity of both ML and ULW, i.e. the ML is not specifically enriched in hydrophobic substances. Low SA/DOC values (Tables 2 and 3) are characteristic of more hydrophilic substances, such as polysaccharides. The hydrophilic nature of the present SAS was also determined by reflection spectroscopy measurements (Kozarac et al., 2005).

In the north Norwegian fjords an inverse relation between surfactant activity and the acidity of organic matter was determined in the upper $40 \mathrm{~m}$ layer in late spring/summer period (Gašparović et al., 2005). Freshly produced biogenic organic matter of phytoplankton origin is surface active and has at the same time lower relative acidity than more refractory humic material. The relative acidity values of organic matter compared between ML and ULW samples, as for example in August 2002, showed a higher abundance of less acidic organic material in the microlayers.

From the surfactant activity measurements (low SA/DOC values and SAS enrichments in MLs, low acidity, same adsorption properties in the ML and ULW) it may be concluded that surface active organic matter in the microlayers in the North Norwegian fjords at the times of sampling mainly originated from new phytoplankton production. This was also observed for the upper $40 \mathrm{~m}$ mixed layer in these fjords in same period (Gašparović et al., 2005).

The organic ligands that can be complexed with $\mathrm{Cu}$ were enriched in microlayer samples up to 5.1 times as revealed by comparison of $L_{T}$ values of MLs and ULWs. The enrichment of complexing ligands was mainly higher compared to DOC and SAS enrichments, an observation that is consistent with the low abundance of organic ligands capable of binding copper in DOC. The enrichment of complexing ligands was more pronounced for June 2001 and July 2003 as compared to August 2002.

Some authors have pointed to the importance of the presence of complexing ligands of low molecular weight (around $270 \mathrm{Da}$ ) in seawater, which are suggested to be produced in situ by organisms (Vachet and Callaway, 2003). Phytoplankton release strong complexing organic ligands that affect dissolved copper speciation (Waeles et al., 2005). Many classes of low molecular weight compounds, with molecular mass between 100 and 1000 Da exhibit $\mathrm{Cu}$ binding in seawater, for example, amino acids, carboxylic acids, and thiols. Carbohydrates in general have low $\mathrm{Cu}$ complexing capacities (Gimenez et al., 1995). If we assume an average 
DOC value of about $2 \mathrm{mg} / 1(165 \mu \mathrm{M})$, complexing capacity values between 0.3 and $1.8 \mu \mathrm{M}$ and molecular mass of ligands between 100 and $1000 \mathrm{Da}$, we estimate that $1-10 \%$ of DOC is present as ligands capable of binding copper ions.

In August the $L_{T}$ values were low in comparison to those in June and July. Note that photochemical conversion of organic matter by sunlight may lead to other low molecular weight organic substances, such as, for example, carboxylic acids (Pullin et al., 2004, and refs therein). The increased sunlight irradiation and daylight period in June and July in the upper surface layer of the investigated sub-arctic region, $\sim 69^{\circ} \mathrm{N}, 19^{\circ} \mathrm{E}$, may have led to the increased concentration of ligands that may complex $\mathrm{Cu}$ ions, as reflected in the high $\mathrm{EF}_{\mathrm{LT}}$, $1.45-5.11$ of these samples.

There are no data in the literature about complexing capacity in microlayer samples to our knowledge; so, direct comparison with our data is not possible. The values for complexing capacity of natural seawater samples from the Adriatic Sea and coastal region of the Aegean Sea were between 0.02 and $1.00 \mu \mathrm{M} \mathrm{Cu}$ (Scoullos et al., 2004; Plavšić et al., 1982; Plavšić, 2003).

The apparent stability constants $(\log K)$ in ML and ULW samples at one sampling site are approximately the same. Differences in $\log K$ could be seen between different sampling sites. In August the range of the apparent stability constants $(\log K 6.8-7.4)$ is the lowest. The highest $\log K$ value was detected in June ( $\log K=7.8$ for ML 5). This would imply that in June ligands possessed high affinity for $\mathrm{Cu}$ ions.

The composition and the concentrations of (surface active) organic substances in seawater are highly dependant on phytoplankton production, which is seasonal. Therefore it may be expected this would be reflected in the concentration of surface active substances in the sea surface microlayer. Late March to late April is a period of the spring bloom that is followed by an additional increase in primary production in the May-June period, due to fresh-water run-off. Primary production is usually rather low for the rest of the year (Eilertsen, et al., 1981; Eilertsen and Taasen, 1984). Congruent with this, our results showed higher surfactant activities of the microlayer samples collected in June and early July, while July samples showed accumulation of organic matter and an increase of DOC values. August samples exhibited lower surfactant activity values, lower concentrations of polyunsaturated FAs, and lower $\mathrm{Cu}$ complexing capacity values as compared to June and July samples. 
Besides variations in different periods there were detected differences in organic matter content and reactivity in different sampling stations that could be related to the characteristics of the environment. More data are needed for a statistically relevant analysis of spatial differences.

Generally, MLs and ULWs were enriched in organic matter in the north Norwegian fjords as found in other coastal areas and under warmer climatic conditions such as in the Adriatic Sea. On the contrary, surface tension measurements as an indication of surfactant accumulation in the ML collected in the open leads of the central Arctic Ocean, showed that surfactant microlayers do occur sparsely in that region as connected to biological activity during short arctic summer (Knulst et al., 2003) .

\section{Conclusions}

In North Norwegian fjords organic matter in the sea surface microlayer is similar to that in the underlying seawater regarding its adsorption properties, surfactant activity normalized to organic carbon content, and apparent stability constants $(\log K)$ for $\mathrm{Cu}$ complexing. Therefore, we conclude that film formation and enrichment of dissolved organic and surface active organic material in the microlayer is derived mainly from organic substances that are present in the subsurface water. An important characteristic of fjord films is relatively low enrichment of SAS. In some cases fatty acids were found in subsurface seawaters of fjords in very high concentrations, up to $188 \mu \mathrm{g} / \mathrm{l}$, while at the same time being depleted in the microlayer. The present organic matter pool is mostly hydrophilic even in the ML. Investigation of acidic properties revealed more acidic substances in the ULW as compared to the ML samples. A low relative acidity of organic substances in the upper layer in late spring/early summer corresponds to freshly produced biogenic organic matter of phytoplankton origin. The enrichment of complexing ligands was generally higher compared to DOC and SAS enrichments, which is in accordance with the fact that complexing ligands represent only 1 to 10 percent of DOC content and they may possess specific reactivity. 
Gašparović, Blaženka; Plavšić, Marta; Ćosović, Božena; Saliot, Alain. Organic matter characterization in the sea surface microlayers in the subarctic Norwegian fjords region. // Marine Chemistry. 105 (2007), 1-2; 1-14. DOI:

10.1016/j.marchem.2006.12.010 - Postprint Version

\section{Acknowledgements}

Financial support of the Croatian Ministry of Science, Education and Sport, grant No. 0098122, and the Norwegian Research Council, CPSEE program, project no. 149583/730 are gratefully acknowledged. The authors wish to thank Dr. Marit Reigstad who kindly provided POC, PON and pigment data and to Mrs. Joëlle Fillaux for fatty acid analyses. Special thanks go to the project leader Dr. Paul Wassmann for general support during the project. Our thanks are also extended to Mr. Zdeslav Zovko for in-field sampling and DOC measurements. 


\section{References}

Andrade, S., Moffet, J., Correa, J.H., 2006. Distribution of dissolved species and suspended particulate copper in an intertidal ecosystem affected by copper mine tailings in Northern Chile, Mar. Chem., in press.

Bazzi, A., Lehman, J.T., Nriagu, J.O., Hollandsworth., Irish, N., Nosher, T., 2002. Chemical speciation of dissolved copper in Saginaw Bay, Lake Huron, with square wave anodic stripping voltammetry. J. Great Lakes Res. 28, 466-478.

Bigg, E.K., Leck, C., Tranvik, L., 2004. Particulates of the surface microlayer of open water in the central Arctic Ocean in summer. Mar. Chem. 91, 131-141.

Brinis, A., Méjanelle, L., Momzikoff, A., Gondry, G., Fillaux, J., Point, V., Saliot, A., 2004. Phospholipid ester-linked fatty acids composition of size-fractionated particles at the top ocean surface. Org. Geochem. 35, 1275-1287.

Buffle, J., 1988. Complexation reactions in aquatic systems. Ellis Horwood, Chichester, p. 692.

Calace, N., Mirante, S., Petronio, B.M., Pietroletti, M., Rugo, C. 2004. Fulvic acid enrichment in the microlayer of the Gerlache Inlet Sea (Antarctica): Preliminary results. Int. J. Env. Anal. Chem. 84, 413-421.

Caldicot, A.B., Eglinton, G., 1973. Surface waxes. In: Miller, L.P. (Ed.), Phytochemistry III. Inorganic Elements and Special Groups of Chemicals. Van Nostrand Reinhold, New York, pp. 162-194.

Carlson, D.J., 1993. The early diagenesis of organic matter reaction at the air-sea interface. In: Engel, M.H. and Macko, S.A. (Eds.), Organic Geochemistry, Plenum Press, New York, pp. 255-268.

Copeman, L.A., Parish, C.C., 2003. Marine lipids in cold coastal ecosystem: Gylbert Bay, Labrador. Mar. Biol. 143, 1213-1227.

Ćosović, B. 2005. Surface-active properties of the sea-surface microlayer and consequences for pollution in the Mediterranean Sea. In: Saliot, A. (Ed.), Hdb Env. Chem. Vol. 5, Part K. Springer, Berlin, pp. 269-296. 
Gašparović, Blaženka; Plavšić, Marta; Ćosović, Božena; Saliot, Alain. Organic matter characterization in the sea surface microlayers in the subarctic Norwegian fjords region. // Marine Chemistry. 105 (2007), 1-2; 1-14. DOI:

10.1016/j.marchem.2006.12.010 - Postprint Version

Ćosović, B., Vojvodić, V., 1982. The application of a.c. polarography to the determination of surface active substances in seawater. Limnol. Oceanogr. 27, 361-369.

Ćosović, B., Žutić, V., Vojvodić, V., Pleše, T., 1985. Determination of surfactant activity and anionic detergents in seawater and sea surface microlayers in the Mediterranean. Mar. Chem. 17, 127-139.

Derieux, S., Fillaux, J., Saliot, A., 1998. Lipid class and fatty acid distributions in particulate and dissolved fractions in the north Adriatic Sea. Org. Geochem. 29, 1609-1621.

Eilertsen, H.C., Falk-Petersen, S., Hopkins, C.C.E., 1981. Ecological investigation on the plankton community of Balsfjorden, northern Norway: Program for the project, study area, topography and physical environment. Sarsia 66, 25-34.

Eilertsen, H.C., Taasen, J.P., 1984. Investigations on the plankton community of Balsfjorden, northern Norway: The phytoplankton 1976-1978. Environmental factors, dynamics of growth, and primary production. Sarsia 69, 1-15.

Falk-Petersen, S., Hoptkins, C.C.E., Sargent, J.R. 1990. Trophic relationships in the pelagic food web. In: Trophic Relationships in the Marine Environment, Barnes, M. and Gibson, R.N. (Eds). Aberdeen University Press, Aberdeen, pp. 315-333.

Falkowska, L., 1999. Sea surface microlayer: a field evaluation of Teflon plate, glass plate and screen sampling techniques. Part 1. Thickness of microlayer samples and relation to wind speed. Oceanologia 41, 211-221.

Garrett, W.D., 1965. Collection of Slick-forming materials from the Sea Surface. Limnol. Oceanogr. 10, 602-605.

Garrett, W. D., 1967. The organic chemical composition of the ocean surface. Deep-Sea Res. $14,221-227$.

Gašparović, B., Ćosović, B., 1994. Electrochemical estimation of the dominant type of surface active substances in seawater samples using o-nitrophenol as a probe. Mar. Chem. 46, 179-188.

Gašparović, B., Ćosović, B., 1995. Electrochemical reduction of o-nitrophenol as a tool for the rough characterization of organic matter in seawater samples. Electroanalysis 7, 1136-1142. 
Gašparović, B., Ćosović, B., Vojvodić, V., 1998a. Contribution of organic acids to the pool of surface active substances in model and marine samples using o-nitrophenol as an electrochemical probe. Org. Geochem. 29, 1025-1032.

Gašparović, B., Kozarac, Z., Saliot, A., Ćosović, B., Möbius, D., 1998b. Physico-chemical characterization of natural and ex-situ reconstructed sea-surface microlayers, J. Colloid Interface Sci. 208, 191-202.

Gašparović, B., Ćosović. B., 2001. Distribution of surface active substances in the Northern Adriatic Sea. Mar. Chem. 75, 301-313.

Gašparović, B., Ćosović. B., 2003. Surface-active properties of organic matter in the North Adriatic Sea. Estuar. Coast. Shelf Sci. 58, 555-566.

Gašparović, B., Plavšić, M, Ćosović. B., Reigstad, M., 2005. Organic matter characterization and fate in the subarctic Norwegian fjords during late spring/summer period. Estuar. Coast. Shelf Sci. 62, 95-107.

Gimenez, M.G., Arino, C., Esteban, M., 1995. Voltammetry of Pb(II), Cd(II), and Zn(II) ions in the presence of the sulfated polysaccharide $\lambda$-carrageenan. Anal. Chim. Acta 310, 121 129.

Goosens, H., Rijpstra, W.I.C., Düren, R.R., de Leeuw, J.W., Schenck P., 1986. Bacterial contribution to sedimentary organic matter; a comparative study of lipid moieties in bacteria and recent sediments. Org. Geochem. 10, 683-696.

Goutx, M., Saliot, A. 1980. Relationship between dissolved and particulate fatty acids and hydrocarbons, chlorophyll $a$ and zooplankton biomass in Villefranche bay, Mediterranean Sea. Mar. Chem. 8, 299-318.

Helbling, E.W., Eilertsen, H.C., Villafañe V.E., Holm-Hansen O., 1996. Effects of UV radiation on post-bloom phytoplankton populations in Kvalsund, North Norway. J. Photochem. Photobiol. B-Biol. 33, 255-259.

ISO 5667-3:1994 Water quality sampling-Part 3. Guidance on the preservation and handling of samples. 
Knulst, J.C., Rosenberger, D., Thompson, B., Paatero, J., 2003. Intensive sea surface microlayer investigations of open leads in the pack ice during Arctic Ocean 2001 expedition. Langmuir 19, 10194-10199.

Kozarac, Z., Klarić, R., Dragčević, Đ., Ćosović, B., 1991. Electrochemical and monolayer studies of the lipid layers at hydrophobic interfaces: Air-water interface and mercury surface. Colloids Surfaces 56, 279-291.

Kozarac, Z., Risović, D., Frka, S., Möbius, D., 2005. Reflection of light from the air/water interface covered with sea-surface microlayers. Mar. Chem. 96, 99-111.

Leck, C., Bigg, E.K., 2005. Biogenic particles in the surface microlayer and overlaying atmosphere in the central Arctic Ocean during summer. Tellus Ser. B-Chem. Phys. Meteorol. 57. 305-316.

Liu, K., Dickhut, R.M., 1998. Effects of wind speed and particulate matter sources on surface microlayer characteristics and enrichment of organic matter in southern Chesapeake Bay. J. Geophys. Res. 103, 10571-10577.

Mantoura, R.F.C, 1981. Organo-metallic interactions in natural waters. In: Duursma, E.K., Dawson, R. (Eds.), Marine Organic Chemistry. Elsevier Oceanography Series, 31, Amsterdam, pp. 179-223.

Marty, J.C., Žutić, V., Precali, R., Saliot, A., Ćosović, B., Smodlaka, N., Cauwet, G., 1988. Organic matter characterization in the Northern Adriatic Sea with special reference to the sea surface microlayer. Mar. Chem. 25, 243-263.

Momzikoff, A., Brinis, A., Dallot, S., Gondry, G., Saliot, A., Lebaron, P., 2004. Field study of the chemical characterization of the upper ocean surface using various samplers. Limnol. Oceanogr.: Methods 2, 374-386.

Nelson, A., Benton, A., 1986. Phospholipid monolayers at the mercury/water interface. J. Electroanal. Chem. 202, 253-270.

Paulson, A.J., Curl, H.C., Gendron, J.F., 1994. Partitioning of Cu in estuarine waters. Control of portioning by the biota. Mar. Chem. 45, 81-93.

Plavšić, M., 2003. Electroanalytical techniques applied for the studying the interaction of organic matter and particles with metal ions in natural waters. Anal. Letters 36, 143-157. 
Plavšić, M., Krznarić, D., Branica, M., 1982. Determination of the apparent copper complexing capacity of seawater by anodic stripping voltammetry. Mar. Chem. 11, 17-31.

Plavšić, M., Ćosović, B., Lee, C., 2006. The copper complexing properties of melanoidins and marine humic material. Sci .Total. Environm. In press.

Pogorzelski, S.J., Kogut, A.D., 2003. Structural and thermodynamic signatures of marine microlayer surfactant films. J. Sea Res. 49, 347-356.

Pullin, M.J., Bertilsson, S., Goldstone, J.V., Voelker, B.M., 2004. Effects of sunlight and hydroxyl radical on dissolved organic matter: Bacterial growth efficiency and production of carboxylic acids and other substrates. Limnol. Oceanogr. 49, 2011-2022.

Ružić, I., 1982. Theoretical aspects of the direct titration of natural waters and its information yield for trace metal speciation. Anal. Chim. Acta 140, 99-113.

Sargent, J.R., Lee, R.F., Nevenzel, J.C., 1976. Marine waxes. In: Kolattukudy P.E. (Ed.), Chemistry and Biochemistry of Natural Waxes. Elsevier, Amsterdam, pp. 49-91.

Sargent, J.R., Gatten, R.R., Mcintosh, R., 1977. Wax esters in the marine environment-their occurrence, formation, transformation and ultimate fate. Mar. Chem. 5, 573-584.

Saliot, A., 1994. Biogéochimie Organique Marine, pp. 197. Océanis, 20. Institut Oceanographique, Paris.

Saliot, A., Tronczynski, J., Scribe P., Letolle, R., 1988. The application of isotopic and biogeochemical markers to the study of the biochemistry of organic matter in a macrotidal estuary, the Loire, France. Estuar. Coast. Shelf Sci. 27, 645-669.

Saliot, A., Parrish, C.C., Sadouni, N., Bouloubassi, I., Fillaux, J., Cauwet, G., 2002. Transport and fate of Danube Delta terrestrial organic matter in the Northwest Black Sea mixing zone. Mar. Chem. 79, 243-259.

Scoullos, M., Plavsic M., Karavoltsos, S., 2004. Copper speciation in the Gulf of Elefsis. The role of macroalgae Ulva rigida. Mar. Chem. 86, 51-63.

Vachet, R.V., Callaway, M.B., 2003. Characterization of $\mathrm{Cu}(\mathrm{II})$-binding ligands from the Chesapeake Bay using high-performance size-exclusion chromatography and mass spectrometry. Mar. Chem. 82, 31-45. 
van den Berg, C.M.G., 1982. Determination of copper complexation with natural organic ligands in seawater by equilibration with $\mathrm{MnO}_{2}$. II Experimental procedures and application to surface seawater. Mar. Chem. 11, 323-342.

Voelker, B.M., Sedlak, D.L., Zafiriou, O.C., 2000. Chemistry of superoxide radical in seawater: Reactions with organic Cu complexes. Environ. Sci. Technol. 34, 1036-1042.

Vojvodić, V., Ćosović, B. Mirić, V., 1994. Fractionation of surface active substances on the XAD-8 resin. Part I. Mixtures of model substances. Anal. Chim. Acta. 295, 73-83.

Waeles, M., Riso, R.D., le Corre, P., 2005. Seasonal variations of dissolved and particulate copper species in estuarine waters. Estuar. Coast. Shelf Sci. 62, 313-323.

Williams, P.M., Carlucci, A.F., Henrichs, S.M., Van Vleet, E.S., Horrigan, S.G., Rheid, F.M.H. and Robertson, K.J., 1986. Chemical and microbiological studies of sea-surface films in the Southern Gulf of California and off the West coast of Baja California. Mar. Chem. 19, 17-98.

Zhou, X., Mopper, K, 1997. Photochemical production of low-molecular-weight carbonyl compounds in seawater and surface microlayer and their air-sea exchange. Mar. Chem, $56,201-213$.

Zuev, B.K., Chudinova, V.V., Kovalenko, V.V., Yagov, V.V., 2001. The conditions of formation of the chemical composition of the sea surface microlayer and techniques for studying organic matter in it. Geochem. Int. 39, 702-710.

Žutić, V., Ćosović, B., Marčenko, E., Bihari, N. Kršinić, F., 1981. Surfactant production by marine phytoplankton. Mar. Chem. 10, 505-520. 

microlayers in the subarctic Norwegian fjords region. // Marine Chemistry. 105 (2007), 1-2; 1-14. DOI:

\subsection{6/j.marchem.2006.12.010 - Postprint Version}

\section{Figures}

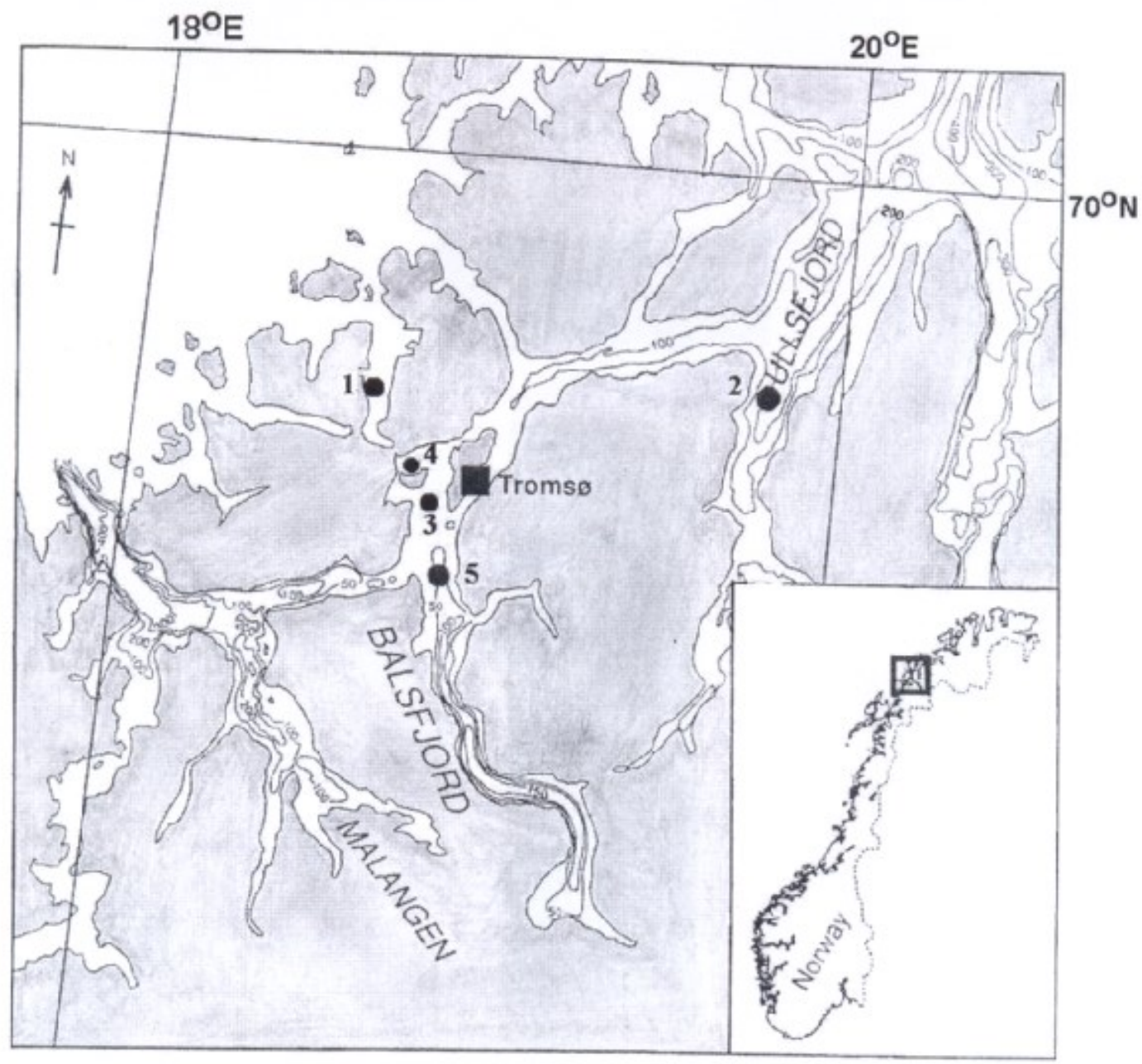

Fig. 1. Sampling stations in the investigated area of North Norwegian fjords 


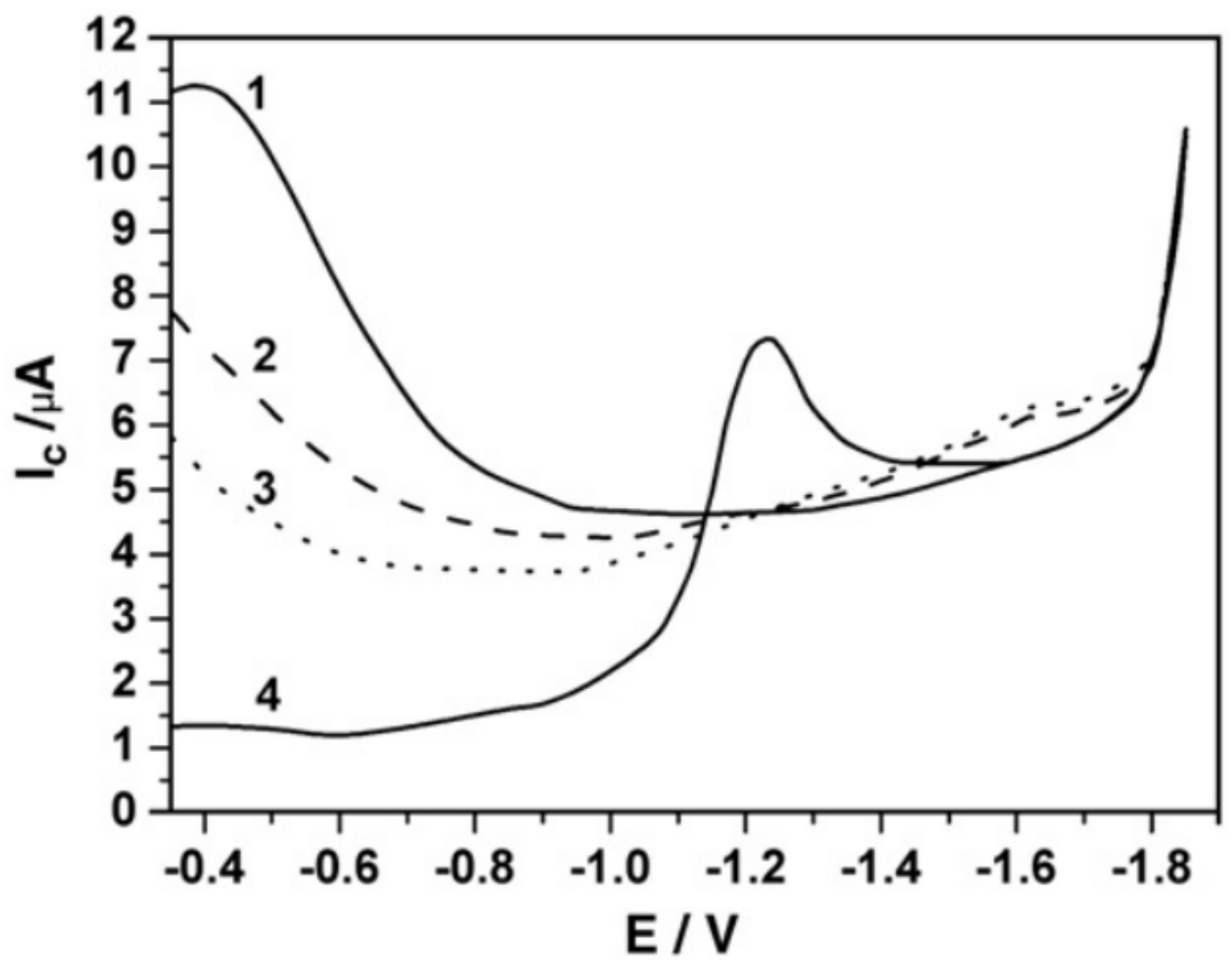

Fig. 2. The capacitive current-potential curves for ULW 3c (curve 2), ML 3c (curve 3), dichloromethane extracted lipids from the ML 3c (curve 4). Curve 1 represents $0 \mathrm{~min}$ accumulation time that is the same for all samples. Accumulation time: 0 min (curve 4) and 3 min (curves 2 and 3 ). 

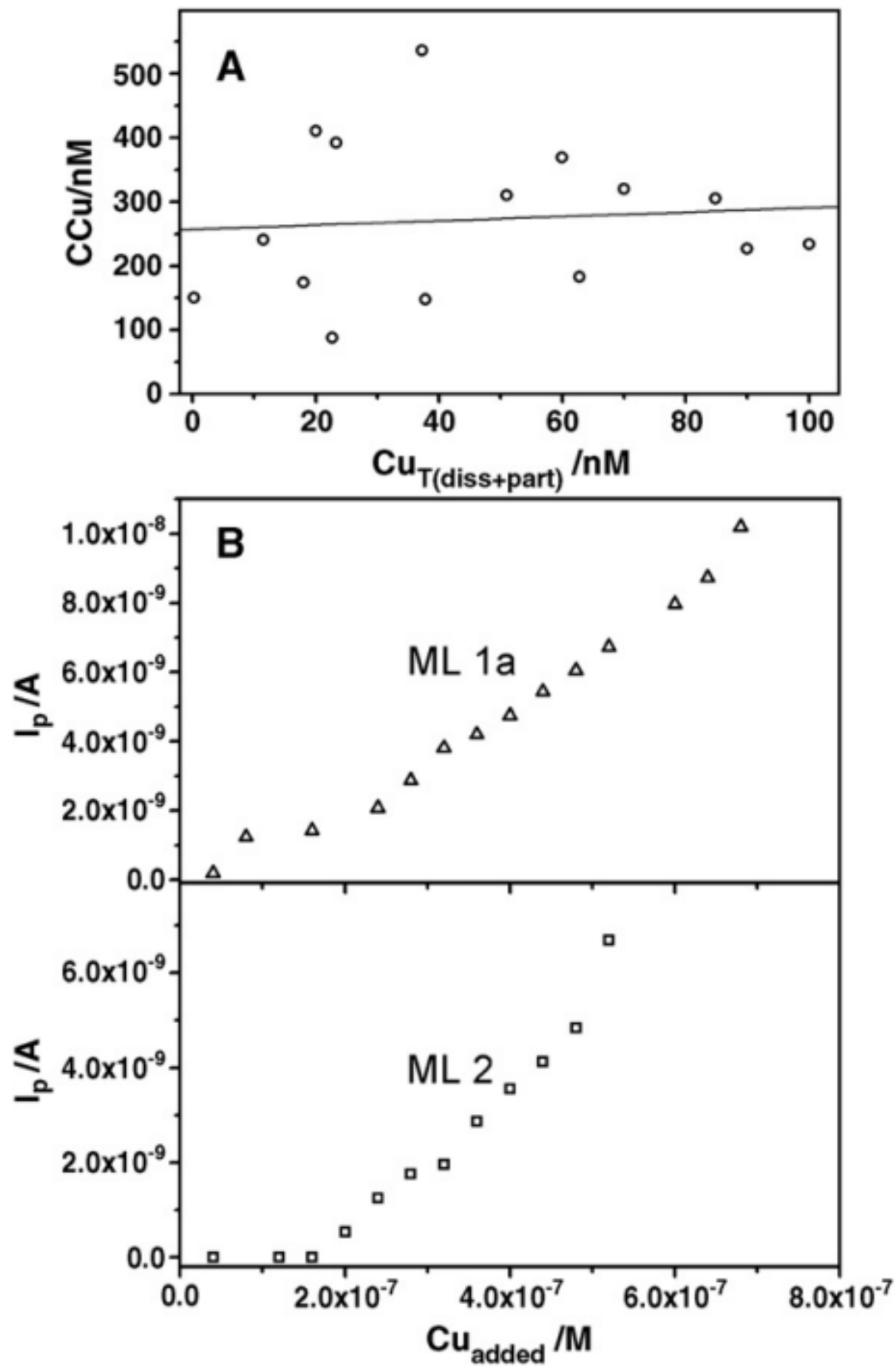

Fig. 3. (A) Copper ion concentrations vs. CCu values; and (B) Titration curves of samples (ML 1a and ML 2) showing oxidation current vs. added copper. 
Gašparović, Blaženka; Plavšić, Marta; Ćosović, Božena; Saliot, Alain. Organic matter characterization in the sea surface microlayers in the subarctic Norwegian fjords region. // Marine Chemistry. 105 (2007), 1-2; 1-14. DOI:

10.1016/j.marchem.2006.12.010 - Postprint Version

\section{Table captions:}

Table 1. Sampling dates and conditions.

Footnote:

${ }^{1}$ The values are means of measurements throughout the $24 \mathrm{~h}$ period up to the end of sampling period. Meteorological data recorded at University of Tromsø during the period of the study. Data obtained from http://weather.cs.uit.no.

Table 2. Dissolved organic carbon (DOC), total surface active substances $\left(\mathrm{SAS}_{\mathrm{T}}\right)$, surface active substances of dissolved fraction $\left(\mathrm{SAS}_{\mathrm{diss}}\right)$, enrichment factors $(\mathrm{EF})$, and relative acidity for the $\mathrm{SAS}_{\mathrm{T}}$ and in brackets for the $\mathrm{SAS}_{\mathrm{diss}}$.

Table 3. Dissolved organic carbon (DOC), particulate organic carbon (POC), particulate organic nitrogen (PON), POC/PON ratio, chlorophyll a (Chl a), total surface active substances $\left(\mathrm{SAS}_{\mathrm{T}}\right), \mathrm{SAS}_{\mathrm{T}}$ normalized to total organic carbon $(\mathrm{DOC}+\mathrm{POC})\left(\mathrm{SAS}_{\mathrm{T}} / \mathrm{TOC}\right)$ are given in brackets, dissolved surface active substances $\left(\mathrm{SAS}_{\text {diss }}\right)$ and $\mathrm{SAS}_{\text {diss }}$ normalized to DOC $\left(\mathrm{SAS}_{\text {diss }} / \mathrm{DOC}\right)$ are given in brackets.

Table 4. Fatty acid concentrations in sea surface microlayer and subsurface seawater expressed in per cent $(\%)$ of given total fatty acids concentrations. EF: enrichment factor.

Footnote:

SAFA: linear saturated fatty acids, MUFA: monounsaturated fatty acids, PUFA: polyunsaturated fatty acids, BrFA: branched saturated fatty acids (iso (i)and anteiso $(a)$ ).

Table 5. Cu complexing capacity $\left(L_{T}\right)$, enrichment factor $(\mathrm{EF})$, apparent stability constant $(\log$ $K$ ) values of $\mathrm{Cu}$ complexes, and $\mathrm{L}_{\mathrm{T}} / \mathrm{DOC}$ and $\mathrm{LT}_{\mathrm{T}} / \mathrm{SAS}$ values.

Footnotes:

${ }^{1}$ Complexing capacity normalized to DOC value in $\mathrm{mg} / 1$

${ }^{2}$ Complexing capacity normalized to SAS value in $\mathrm{mg} / \mathrm{l} \mathrm{T}-\mathrm{X}-100$ 
Table 1

\begin{tabular}{|c|c|c|c|c|c|c|c|}
\hline Sample & date & $\begin{array}{c}\text { Sampling } \\
\text { time, } \\
\mathrm{h} \\
\end{array}$ & $\begin{array}{l}\text { Weather } \\
\text { conditions }\end{array}$ & $\begin{array}{c}\text { Solar } \\
\text { irradiance }^{1}, \\
\mathrm{~W} / \mathrm{m}^{2}\end{array}$ & $\begin{array}{c}\mathrm{T}_{\text {air }}^{1}, \\
{ }^{\circ} \mathrm{C}\end{array}$ & $\begin{array}{c}\text { Wind speed }^{1}, \\
\mathrm{~m} / \mathrm{s}\end{array}$ & $\begin{array}{l}\mathrm{T}_{\text {sea, }} \\
{ }^{\circ} \mathrm{C}\end{array}$ \\
\hline 2001 & & & & & & & \\
\hline $\begin{array}{l}\text { ML 1a } \\
\text { ULW 1a }\end{array}$ & 06.07 .01 & $20-22$ & $\begin{array}{l}\text { sunny with } \\
\text { clouds }\end{array}$ & 145.82 & 10.11 & 0.40 & 11 \\
\hline $\begin{array}{c}\text { ML 1b } \\
\text { ULW 1b }\end{array}$ & 07.07 .01 & $8.30-10.30$ & $\begin{array}{c}\text { mostly } \\
\text { sunny }\end{array}$ & 190.46 & 11.82 & 0.40 & 12 \\
\hline $\begin{array}{c}\text { ML } 2 \\
\text { ULW } 2\end{array}$ & 08.07 .01 & $13-15$ & $\begin{array}{l}\text { mostly sunny } \\
\text { waves }\end{array}$ & 233.44 & 12.72 & 1.18 & $\begin{array}{l}9 \\
9\end{array}$ \\
\hline 2002 & & & & & & & \\
\hline $\begin{array}{c}\text { ML 3a } \\
\text { ULW 3a }\end{array}$ & 20.08 .02 & $9-11$ & sunny & 78.20 & 14.54 & 1.19 & $\begin{array}{l}13.5 \\
11.5\end{array}$ \\
\hline $\begin{array}{c}\text { ML 3b } \\
\text { ULW 3b }\end{array}$ & 21.08 .02 & $8.45-10.45$ & sunny & 195.35 & 17.89 & 1.32 & $\begin{array}{c}13.5 \\
11\end{array}$ \\
\hline $\begin{array}{c}\text { ML } 4 \\
\text { ULW } 4\end{array}$ & 21.08 .02 & 11-13 & sunny & 203.98 & 20.10 & 1.46 & $\begin{array}{l}15.5 \\
13.5\end{array}$ \\
\hline $\begin{array}{c}\text { ML 3c } \\
\text { ULW 3c }\end{array}$ & 22.08 .02 & $9-11$ & cloudy & 146.78 & 16.84 & 1.05 & $\begin{array}{l}14 \\
13\end{array}$ \\
\hline $\begin{array}{c}\text { ML 3d } \\
\text { ULW 3d }\end{array}$ & 26.08 .02 & $9-11$ & $\begin{array}{l}\text { cloudy } \\
\text { small rain }\end{array}$ & 88,65 & 11.80 & 3.24 & $\begin{array}{l}11 \\
11 \\
\end{array}$ \\
\hline $\begin{array}{c}\mathbf{2 0 0 3} \\
\text { ML 5 } \\
\text { ULW 5 }\end{array}$ & 06.06 .03 & $9-11$ & sunny & 376.02 & 13.03 & 2.04 & $\begin{array}{c}15.9 \\
10\end{array}$ \\
\hline
\end{tabular}


Table 2

\begin{tabular}{|c|c|c|c|c|c|c|c|}
\hline Sample & $\begin{array}{l}\mathrm{DOC} \\
\mathrm{mg} / \mathrm{l}\end{array}$ & $\mathrm{EF}_{\mathrm{DOC}}$ & $\begin{array}{c}\mathrm{SAS}_{\mathrm{T}} \\
\mathrm{mg} / 1 \mathrm{~T}-\mathrm{X}-100\end{array}$ & $\begin{array}{c}\mathrm{EF} \\
\left(\mathrm{SAS}_{\mathrm{T}}\right)\end{array}$ & $\begin{array}{c}\text { SAS }_{\text {diss }} \\
\mathrm{mg} / 1 \mathrm{~T}-\mathrm{X}-100\end{array}$ & $\mathrm{EF}\left(\mathrm{SAS}_{\mathrm{diss}}\right)$ & $\begin{array}{c}\text { Relative } \\
\text { acidity } \\
1 / \mathrm{mg}\end{array}$ \\
\hline \multicolumn{8}{|l|}{ July, 2001} \\
\hline ML 1a & 2.83 & 1.87 & 0.164 & 1.21 & 0.158 & 1.28 & - \\
\hline ULW 1a & 1.51 & & 0.135 & & 0.123 & & 13.3 \\
\hline ML 1b & 2.77 & 1.50 & $>0.21$ & 1.57 & 0.162 & 1.45 & $(6.2)$ \\
\hline ULW 1b & 1.85 & & 0.138 & & 0.112 & & 15.9 \\
\hline ML 2 & 2.08 & 1.72 & $>0.21$ & $>2.8$ & 0.160 & 2.50 & $(12.5)$ \\
\hline ULW 2 & 1.21 & & 0.075 & & 0.064 & & 9.7 \\
\hline \multicolumn{8}{|l|}{ August, 2002} \\
\hline ML 3a & - & - & 0.133 & 1.24 & & & 7.4 \\
\hline ULW 3a & - & & 0.107 & & & & 7.8 \\
\hline ML 3b & 1.92 & - & 0.138 & 1.37 & & & 4.4 \\
\hline ULW 3b & - & & 0.101 & & & & 10.9 \\
\hline ML 4 & 2.21 & 1.57 & 0.140 & 1.4 & & & 5.3 \\
\hline ULW 4 & 1.41 & & 0.100 & & & & 13.1 \\
\hline ML 3c & 2.09 & 1.45 & 0.121 & 1.44 & & & 3.0 \\
\hline ULW 3c & 1.44 & & 0.084 & & & & 3.2 \\
\hline ML 3d & 2.59 & 1.52 & 0.134 & 1.34 & & & 6.0 \\
\hline ULW 3d & 1.71 & & 0.100 & & & & 12.6 \\
\hline \multicolumn{8}{|l|}{ June, 2003} \\
\hline ML 5 & 1.67 & 1.19 & $>0.210$ & $>1.7$ & 0.142 & 1.21 & $(9.1)$ \\
\hline ULW 5 & 1.40 & & 0.122 & & 0.117 & & 10.1 \\
\hline
\end{tabular}


Table 3.

\begin{tabular}{cccccccc}
\hline $\begin{array}{c}\text { Depth } \\
(\mathrm{m})\end{array}$ & $\begin{array}{c}\mathrm{DOC} \\
\mathrm{mg} / 1\end{array}$ & $\begin{array}{c}\text { POC } \\
\mathrm{mg} / 1\end{array}$ & $\begin{array}{c}\text { PON } \\
\mathrm{mg} / 1\end{array}$ & POC/PON & $\begin{array}{c}\text { Chl } a \\
\mu \mathrm{g} / 1\end{array}$ & $\begin{array}{c}\mathrm{SAS}_{\mathrm{T}} \\
\left(\mathrm{SAS}_{\mathrm{T}} / \mathrm{TOC}\right) \\
\mathrm{mg} / 1 \mathrm{~T}-\mathrm{X}-100\end{array}$ & $\begin{array}{c}\mathrm{SAS}_{\text {diss }} \\
\left(\mathrm{SAS}_{\text {diss }} / \mathrm{DOC}\right) \\
\mathrm{mg} / 1 \mathrm{~T}-\mathrm{X}-100\end{array}$ \\
\hline ML 5 & 1.67 & 0.431 & 0.046 & 10.83 & 0.749 & $>0.21(>0.1)$ & $0.142(0.072)$ \\
ULW 5 & 1.40 & 0.293 & 0.037 & 9.07 & 0.963 & $0.122(0.072)$ & $0.117(0.083)$ \\
5 & 1.20 & 0.304 & 0.044 & 7.88 & 1.477 & $0.121(0.080)$ & $0.104(0.087)$ \\
10 & 1.13 & 0.239 & 0.035 & 7.74 & 2.011 & $0.112(0.082)$ & $0.092(0.081)$ \\
20 & 1.16 & 0.158 & 0.024 & 8.23 & 0.694 & $0.103(0.078)$ & $0.055(0.047)$ \\
30 & 1.17 & 0.252 & 0.038 & 7.53 & 1.712 & $0.117(0.082)$ & $0.087(0.074)$ \\
50 & 1.34 & 0.081 & 0.008 & 11.08 & 0.207 & $0.070(0.050)$ & $0.070(0.052)$ \\
60 & 1.28 & 0.078 & 0.009 & 10.01 & 0.121 & $0.075(0.055)$ & $0.075(0.058)$ \\
\hline
\end{tabular}


Table 4.

\begin{tabular}{|c|c|c|c|c|c|c|c|c|c|c|c|c|c|c|c|c|c|c|}
\hline July & & $1 \mathrm{~b}$ & & 2 & & $\begin{array}{l}200 \\
3 a\end{array}$ & Augu & t & & 4 & & & $\begin{array}{l}3 \mathbf{c} \\
\mathrm{MI}\end{array}$ & & & $\begin{array}{l}\text { 3d } \\
M L\end{array}$ & & \\
\hline ULW & EF & ML & ULW & ML & ULW & ML & ULW & ML & ULW & ML & ULW & EF & ML & ULW & EF & ML & ULW & $\mathbf{E}$ \\
\hline 156.7 & 0.4 & $\mathrm{~nm}$ & 63.3 & $\mathrm{~nm}$ & 188.3 & $\mathrm{~nm}$ & 23.8 & 9.8 & $\mathbf{n m}$ & 75.3 & 7.5 & 10.2 & 44.2 & 2.1 & 20.6 & 56.2 & 69.9 & 0 \\
\hline 29.5 & 0.5 & & 61.3 & & 46.4 & & 64.7 & 66.9 & & 43.5 & 61.4 & 7.3 & $\begin{array}{c}46.4 \\
0.1\end{array}$ & 52.7 & 18.2 & $\begin{array}{c}\mathbf{4 5 . 2} \\
0.7\end{array}$ & 45.9 & \\
\hline 7.8 & 1.0 & & 10.8 & & 16.7 & & 30.2 & 16.4 & & 10.7 & 19.0 & 5.8 & 7.5 & 5.5 & 28.2 & 14.1 & 13.5 & \\
\hline 16.3 & 0.3 & & 47.2 & & 21.1 & & 26.9 & 32.2 & & 28.3 & 37.6 & 7.7 & 29.8 & 36.9 & 16.7 & 28.3 & 27.4 & \\
\hline 5.2 & 0.3 & & 3.2 & & 8.6 & & 7.6 & 18.3 & & 4.5 & 4.8 & 9.5 & 9.0 & 10.4 & 18.0 & 2.1 & 5.0 & \\
\hline 0.3 & 3.0 & & & & & & & & & & & & & & & & & \\
\hline 38.5 & 0.1 & & 10.0 & & 19.0 & & 21.7 & $\begin{array}{c}\mathbf{1 4 . 5} \\
0.4\end{array}$ & & 24.3 & 32.0 & 7.8 & 32.6 & 22.4 & 30.0 & $\begin{array}{c}\mathbf{2 8 . 9} \\
1.6\end{array}$ & 26.6 & \\
\hline 2.8 & & & 5.5 & & 1.5 & & & 1.5 & & & & & 3.8 & & & 5.2 & & \\
\hline 2.6 & 2.4 & & & & & & 6.8 & 4.9 & & 9.5 & 23.4 & 4.2 & 8.5 & 8.0 & 21.9 & 10.9 & 13.6 & \\
\hline 32.4 & 0.2 & & 4.5 & & $\begin{array}{c}14.0 \\
3.0\end{array}$ & & 9.0 & 6.3 & & 13.0 & 6.9 & 19.2 & 18.5 & 14.4 & 26.5 & 9.0 & 10.7 & \\
\hline 0.7 & & & & & 0.6 & & 5.9 & 1.3 & & 1.8 & 1.7 & 10.8 & 1.8 & & & 2.1 & 2.3 & \\
\hline 27.7 & 0.7 & & 16.6 & & 27.9 & & 2.5 & 10.6 & & 25.2 & 3.2 & 79.3 & 13.9 & 21.4 & 13.4 & 17.7 & 20.7 & \\
\hline 2.6 & 0.2 & & 2.7 & & 1.6 & & 1.8 & 2.5 & & & 1.7 & & 7.3 & 6.4 & 23.4 & 3.2 & 3.9 & \\
\hline 1.0 & 1.1 & & 0.6 & & 1.1 & & 0.8 & 0.5 & & 2.4 & 0.8 & 31.5 & 1.9 & 2.8 & 14.2 & 0.9 & 1.4 & \\
\hline 2.2 & 1.3 & & 1.6 & & 5.9 & & & 1.9 & & 4.1 & & & 1.2 & & & 2.6 & 3.1 & \\
\hline 0.3 & & & 5.6 & & & & & & & & & & & & & & & \\
\hline 0.6 & 0.6 & & 0.2 & & 0.5 & & & & & & & & 0.6 & & & 0.2 & 0.4 & \\
\hline 7.6 & 1.7 & & 3.1 & & 9.8 & & & 2.5 & & 6.1 & 0.7 & 87.4 & 1.8 & 7.7 & 4.9 & 6.0 & 10.0 & \\
\hline 13.3 & 0.1 & & 2.7 & & 9.0 & & & 3.2 & & 12.5 & & & 1.0 & 4.4 & 4.7 & 4.8 & 1.9 & \\
\hline 4.3 & 0.4 & & $\begin{array}{r}12.1 \\
0.7\end{array}$ & & 6.7 & & 11.1 & $\begin{array}{c}7.6 \\
1.6\end{array}$ & & 7.0 & 3.4 & 20.7 & 7.1 & 3.5 & 42.1 & $\begin{array}{c}8.2 \\
0.4\end{array}$ & 6.8 & \\
\hline 0.6 & & & 2.8 & & 1.5 & & 1.0 & 0.4 & & 0.3 & 0.6 & 5.5 & 0.6 & & & 0.9 & 0.8 & \\
\hline 0.8 & & & 2.6 & & 0.9 & & 0.7 & 0.5 & & 0.8 & 0.6 & 13.6 & 0.7 & & & 0.9 & 0.7 & \\
\hline 1.3 & 0.5 & & 1.8 & & 1.4 & & 5.3 & 2.5 & & 2.7 & 1.8 & 15.2 & 2.2 & 1.7 & 27.2 & 2.6 & 2.0 & \\
\hline 0.3 & & & 1.2 & & 0.4 & & 1.5 & & & 0.8 & 0.4 & 17.8 & 0.9 & & & 1.1 & 0.8 & \\
\hline & & & & & 1.1 & & & 1.1 & & 0.5 & 1.3 & 4.3 & 0.8 & & & 0.3 & & \\
\hline 0.5 & 0.9 & & 1.8 & & 0.4 & & & & & 0.5 & & & 0.4 & & & 0.6 & 0.4 & \\
\hline 0.8 & 0.8 & & 1.1 & & 1.1 & & 2.6 & 1.5 & & 1.4 & 4.7 & 3.0 & 1.4 & 1.8 & 15.8 & 1.5 & 2.1 & \\
\hline
\end{tabular}


Table 5

\begin{tabular}{cccccc}
\hline Sample & $\begin{array}{c}\mathrm{L}_{\mathrm{T}} \\
\left(\mu \mathrm{M} \mathrm{Cu}^{2+} / \mathrm{l}\right)\end{array}$ & EF & $\begin{array}{c}\mathrm{Log} \mathrm{K} \\
\left(1 / \mathrm{mol} \mathrm{Cu}^{2+}\right)\end{array}$ & $\begin{array}{c}\mathrm{L}_{\mathrm{T}} / \mathrm{DOC}^{1} \\
(\mu \mathrm{M} / \mathrm{mg})\end{array}$ & $\begin{array}{c}\mathrm{L}_{\mathrm{T}} / \mathrm{SAS}^{2} \\
(\mu \mathrm{M} / \mathrm{mg})\end{array}$ \\
\cline { 1 - 2 } July, 2001 & & & & & \\
ML 1a & 0.54 & 1.45 & 7.0 & 0.19 & 3.3 \\
ULW 1a & 0.37 & & 7.0 & 0.24 & 2.7 \\
ML 1b & 1.79 & 5.11 & 7.3 & 0.65 & 8.3 \\
ULW 1b & 0.35 & & 7.4 & 0.19 & 2.5 \\
ML 2 & 0.39 & 4.33 & 7.5 & 0.19 & $<2.4$ \\
ULW 2 & 0.09 & & 7.7 & 0.07 & 1.2 \\
\hline August, 2002 & & & & & \\
ML 3a & 0.23 & 1.35 & 7.1 & - & 1.7 \\
ULW 3a & 0.17 & & 6.9 & - & 1.6 \\
ML 3b & 0.31 & & 7.0 & 0.16 & 2.3 \\
ULW 3b & - & & - & - & - \\
ML 4 & 0.31 & 2.07 & 7.4 & 0.14 & 2.2 \\
ULW 4 & 0.15 & & 7.3 & 0.11 & 1.5 \\
ML 3c & 0.23 & 1.28 & 7.1 & 0.11 & 1.9 \\
ULW 3c & 0.18 & & 7.5 & 0.13 & 2.1 \\
ML 3d & 0.32 & 1.33 & 6.8 & 0.12 & 2.4 \\
ULW 3d & 0.24 & & 6.8 & 0.14 & 2.4 \\
\hline June, 2003 & & & & & \\
ML 5 & 0.41 & 2.73 & 7.8 & 0.25 & 2.0 \\
ULW 5 & 0.15 & & 7.6 & 0.11 & 1.2 \\
\hline
\end{tabular}

